\title{
Nut density and removal in Syagrus loefgrenii Glassman (Arecaceae) in the Brazilian Cerrado
}

\author{
J. Ragusa-Netto ${ }^{a *}$ \\ Departamento de Ciências Naturais, Universidade Federal do Mato Grosso do Sul - UFMS, Campus Três Lagoas, \\ Av. Ranulpho Marques Leal, 3484, CP 210, CEP 79610-100, Três Lagoas, MS, Brazil \\ *e-mail: jragusanetto@yahoo.com
}

Received: 10 February, 2015 - Accepted: 22 May, 2015 - Distributed: 31 August, 2016

(With 3 figures)

\begin{abstract}
In this study, I tested the effect of Syagrus loefgrenii nut number on the removal intensity by rodents across seasons. Also, I assessed both $S$. loefgrenii fruit production, and dispersion pattern to analyze the relationship between these parameters and nut removal. Trials were performed (autumn, winter, spring, and summer), in which endocarps were placed inside trays $(5,15$, and 40 endocarps) in the Cerrado (Brazilian savanna). Syagrus loefgrenii exhibited clumped distribution, although its local density had no correlation with endocarp removal rate. Despite of variations, S. loefgrenii fruit production had no seasonal difference, although, high proportions of endocarps were year round removed. This mostly results from nearly complete endocarp loss in depots of 5 and 15 , while the opposite occurred in those of 40. Hence, the intensity of removal consistently decreases with endocarp number, so that endocarp removal conformed to negative distance-dependence. As this palm exhibit clumped distribution and, in principle, fruit asynchronously, if, at least, a group of neighboring stems bore fruits simultaneously, an enhanced number of nuts might be available at a given site. Therefore, seeds within a dense $S$. loefgrenii fruit patch might experience high survival rates due to satiation of post dispersal seed predators.
\end{abstract}

Keywords: seed predation, distance-dependence, plant-animal interaction, palm fruits, Brazil, Cerrado palm.

\section{Densidade de sementes e remoção em Syagrus loefgrenii Glassman (Arecaceae) no Cerrado brasileiro}

\begin{abstract}
Resumo
Neste estudo, testei o efeito da densidade de endocarpos de Syagrus loefgrenii sobre a intensidade de remoção por roedores conforme a estação do ano. Também, avaliei tanto a produção de frutos, quanto o padrão de dispersão dessa palmeira em relação à intensidade de remoção de endocarpos. Executei experimentos no Cerrado (outono, inverno, primavera e verão), nos quais acondicionei 5, 15 e 40 endocarpos em pratos plásticos perfurados (pilhas experimentais). Syagrus loefgrenii exibiu distribuição agrupada. Apesar disso, a densidade local dessa palmeira em nenhuma estação esteve correlacionada com a taxa de remoção de endocarpos. Não ocorreram diferenças temporais significativas quanto aos níveis de frutificação, e, simultaneamente, documentei intensa remoção de endocarpos. Isso ocorreu, sobretudo, nas pilhas com 5 e 15 endocarpos, as quais, na maioria dos casos, perderam quase todos endocarpos. No entanto, as pilhas com 40 perderam poucos diásporos. Nesse sentido a intensidade de remoção decresceu consistentemente conforme o número de endocarpos, tal que esse processo mostrou ser negativamente dependente da distância. Syagrus loefgrenii exibiu padrão agrupado de distribuição, além de produzir frutos assincronicamente. Nesse sentido, caso um grupo de palmeiras vizinhas frutifique simultaneamente, uma grande quantidade de diásporos estará disponível em um dado local. Portanto, sementes em meio a uma densa carga de frutos podem ser favorecidas, uma vez que predadores pós-dispersão seriam saciados.
\end{abstract}

Palavras-chave: predação de sementes, distância-dependente, interação planta-animal, frutos de palmeira, Brasil, palmeira do Cerrado.

\section{Introduction}

Palms are present in wide range of habitat types exhibiting diverse life forms ranging from tall trees to herb-like plants with subterranean stem (Henderson, 2002; Eiserhardt et al., 2011). Due to their diversity and abundance, palms are one of the most important plant groups in tropical areas (Henderson, 2002; Eiserhardt et al., 2011). Indeed, they have influence on the function of many tropical ecosystems (Kahn and Mejia, 1991; Henderson, 2002). Palms constitute 
an interesting model for studying plant-animal interactions due to a broad spectrum of relationships, which range from predation to mutualism with both invertebrates and vertebrates (Henderson, 2002). These animals often eat their fruits, seeds, and seedlings, besides the fact that during famine, palms may be important by providing a key food resource for a wide range of vertebrates (Kiltie, 1981; Zona and Henderson, 1989; Peres, 1994, 2000). This mostly results from extend or asynchronous fruiting periods present in many species both at the individual and population levels. Then, their fruits might be available all year round, mainly when non palm plants have no fruits (Peres, 1994, 2000). Besides that, some palms are among the most abundant species fruiting at a given area (Peres, 1994). Their fallen or dispersed nuts may remain on the ground for weeks before they are scatter-hoarding (Smythe, 1989), or eaten by terrestrial vertebrates (Kiltie, 1981).

Seed predation is an important cause of mortality throughout the life cycle of plants and one of the major processes underlying plant recruitment patterns (Janzen, 1970; Hulme, 1998; Packer and Clay, 2003; Terborgh, 2012), colonization ability (De Steven, 1991; Myster and Pickett, 1993; Nathan and Casagrandi, 2004), spatial distribution (Terborgh, 2012), and reproductive ecology of trees (Sork, 1993). Janzen (1970) initially identified the importance of density or distance-dependent seed predation in the dynamics of tropical trees. Distance-dependence would favor greater survival of offspring further away from the parent which would lead to a more uniform distribution of adults and, thus, facilitate species co-existence (Swamy and Terborgh, 2010; Terborgh, 2012). While some studies show the effect of soil pathogens near parental plants in reducing the survival of conspecific seeds (Packer and Clay, 2003; Bagchi et al., 2010), others have focused on the distinct effects of invertebrates and vertebrates on seed survival and plant communities (Wright, 2002; Bagchi et al., 2010). Invertebrates are often distance-responsive specialized seed predators that generally generate patterns conforming to the Janzen model, whereas mobile and generalist vertebrates may generate other kind of patterns (Romo et al., 2004).

Post-dispersal seed predation may be either positively or negatively distance-dependent in relation to the relative abundance of seeds and their predators. When food resources are scarce for a particular seed predator population, predation is likely to be positively distance-dependent, but when the resources are abundant, seed predators become satiated and a negatively distance-dependent response is expected to occur (Janzen, 1970; Wright, 1990; Augspurger and Kitajima, 1992; Jansen et al., 2014). Lack of response may occur if factors other than the relative abundance of seeds determine the behavior of seed predators (Chauvet et al., 2004; Romo et al., 2004).

Syagrus loefgrenii Glassman is a small palm with subterranean stem from Cerrado of Southwestern Brazil (Lorenzi et al., 2010). Previous observations suggested non seasonal fruit production in S. loefgrenii (1 to 30 nuts/infrutescence), as in other palm species (Peres, 1994, 2000). As S. loefgrenii might produces fruits all year round, presumably, is important in the diet of rodents (Bueno et al., 2004). Also, S. loefgrenii often has multiple stems (Lorenzi et al., 2010). Then, patches of high resource density, as might be found in groves of fruiting trees, can be expected to attract higher densities of seed predators relative to isolated trees (Janzen, 1970). Particularly, palm spatial aggregation may affect removal of palm nuts by frugivores (Beck and Terborgh, 2002). Hence, at a given place and time of the year, palm nut availability may be high variable according to the number of fruiting stems. Also, both abundance and activity pattern of Cerrado rodents vary seasonally (Mares et al., 1986; Vieira, 1997; Vieira, 1999). Therefore, palm nuts and rodents abundance, potentially, exhibit pronounced changes which may affect nut removal rate. Then, I tested the effect of $S$. loefgrenii nut number and seasonality on the removal intensity by rodents. Also, I assessed both S. loefgrenii fruit production, and dispersion pattern to analyze the relationship between these parameters and nut removal. Specifically, I evaluated whether endocarp removal intensity conformed to distance-dependence across seasons. Indeed, depending on endocarp number at a given patch, removal intensity might be either higher, or lower than expected under the assumption of independence. In the first case positive distance-dependence is expected, while negative distance-dependence may occur in the second. On the other hand, if removal intensity is independent of the amount of endocarps available, removal is distanceindependent. Any of these patterns might change from season to season conform fruit availability and/or the abundance of seed predators.

\section{Material and Methods}

Study site. This study was developed from April 2013 to March 2014 in the Cerrado (Brazilian savanna) of Estação Ecológica de Itirapina (EEI), in the municipalities of Itirapina and Brotas (State of São Paulo, Brazil: $22^{\circ} 15^{\prime} \mathrm{S}$ and $47^{\circ} 49^{\prime} \mathrm{W}$; altitude varies between 700 and $750 \mathrm{~m}$ ) including an area of 2,720 ha. Mean annual temperature is $19.7^{\circ} \mathrm{C}$. Higher mean temperature is recorded in January and February $\left( \pm 22.5^{\circ} \mathrm{C}\right)$. In June and July mean temperature is $16.3^{\circ} \mathrm{C}$. During this period, the day-break temperature often drops to $2^{\circ} \mathrm{C}$ or less and frost may occur. Mean annual rainfall is around $1400 \mathrm{~mm}$, with $1000 \mathrm{~mm}$ between October and March. Hence, there is a wet-hot season extending from October to March and a dry-cold season from April to September, when large number of trees and bushes shed their leaves. There are cattle ranching, housing (a condominium), Pinus spp. and Eucalyptus spp. plantations as land uses surrounding the reserve. The main threats to the EEI are the expansion of African grasses, Urochloa decumbens and Melinis minutiflora, and exotic trees, including Pinus and Eucalyptus spp. Other disturbance factors are hunters and exotic animals such as cattle, pigs and goats (Motta-Junior et al., 2008). The deciduous Cerrado vegetation consists mainly of a continuous ground layer dominated by grasses, and a 
woody layer varying in ground cover from 10 to $20 \%$ of trees of 2-6 m high. Common tree species are Pouteria torta, Hancornia speciosa, Stryphnodendron obovatum, Anadenathera falcata, and Couepia grandiflora (pers. observ.). The richest plant families are Asteraceae, Fabaceae, and Poaceae (Tannus and Assis, 2004).

Study species. Syagrus loefgrenii Glassman is a monoecious palm with inclined subterranean stem, rarely more than $0.7 \mathrm{~m}$ tall, has 4-8 erect leaves with 26-66 leaflets at each leaf side, irregularly arranged across the raquis, and is confined to Cerrado of the Brazilian State of São Paulo (Lorenzi et al., 2010).

Spatial distribution. Syagrus loefgrenii local density might affect endocarp removal from experimental depots (see below). Then, to sample both abundance and spatial distribution of $S$. loefgrenii adult population (fertile individuals), I established a $1.5-\mathrm{km}$-long transect in which I positioned 45 points ( $30 \mathrm{~m}$ apart from each other) in April 2013. At every point I counted all S. loefgrenii stems within a $3 \mathrm{~m}$ ray. I used a standardized Morisita's Index of Dispersion (Morisita, 1962) to evaluate the distribution pattern of $S$. loefgrenii adults in the sampled area. This index ranges from -1.0 to +1.0 , with $95 \%$ confidence limits at +0.5 and -0.5 . Random patterns give an $\mathrm{I}_{\mathrm{P}}=0$, clumped patterns an $\mathrm{I}_{\mathrm{P}}>0$, and uniform patterns an $\mathrm{I}_{\mathrm{p}}<0$ (Krebs, 1989).

Fruit production. Taking into account the potential intra-seasonal changes in $S$. loefgrenii fruit production, I assessed fruit availability during the year by counting fruiting palms intercepted by transect described above. In fact, I searched for fruiting palms in the first week of the second month of the four periods of the year: the late wet season (January-March), the early dry season (AprilJune), the late dry season (July-September), and the early wet season (October-December). Whenever I detected a fruiting palm, I counted the number of palm nuts per infrutescence and took the number of fruits per palm as replicate to compare fruit availability in the four periods of the year. These data collection coincided with the beginning of experiments on endocarp removal (see below). I only recorded a next palm if it was at least $5 \mathrm{~m}$ apart to avoid sampling stems from the same palm. As unripe palm fruits may spend prolonged periods ( $>1-3$ months) for maturation, I sampled only those infrutescences with mature, unfasten fruits, which, in principle, were available for frugivores.

Experimental design. The experiment was designed to compare endocarp removal rates in relation to endocarp number and year period (see above), in 45 experimental endocarp piles. Round shallow black plastic trays $(15 \mathrm{~cm}$ diameter $\times 1 \mathrm{~cm}$ deep) were used to prevent endocarps being washed away or lost during rain events. Small drainage holes were drilled in the tray bases. Trays were embedded in the soil and stabilized using wood pegs. In each trial endocarps were placed inside trays, hereafter referred to as depots, which included 5, 15, and 40 endocarps (in each case $n=15$ ). I delineated these numbers based in previous observation in which many palms had infrutescences with reduced number of nuts (around 5), others with intermediate (15), and in some cases large number of nuts may be available when neighboring stems bore fruits simultaneously (40). The 45 depots used in the experiment were located on the points along transect described above, and the disposition of depots conform endocarp number was rotated. Each depot was assumed as a replicate for analyses as $30 \mathrm{~m}$ assure independence between samples (Chauvet and Forget, 2005). An area of approximately $50 \mathrm{~cm}^{2}$ was cleared of grass or leaf litter for the placement of each depot. Depots with endocarps were set out 10 April 2013, 6 August 2013, 7 November 2013, and 4 February 2014, in order to run trials during the middle of each of the four period of the year. Endocarps were counted and removed from depots after 40 days, between 10:30 and 14:30. Any endocarp that was preyed upon in situ (confirmed by the presence of a hole with rodent teeth marks), or removed was considered to have been subject to predation, while those remaining in the depots were considered to have survived. However, because I do not know the fate of each endocarp after they were removed from depots, rates of endocarp removal will be used instead of endocarp predation when discussing the results. For each trial I collected $>$ $900 \mathrm{~S}$. loefgrenii fruits from over 50 palms located in the understory of a Pinus ellioti plantation which is part of the EEI. In this site $S$. loefgrenii was highly abundant and infrutescences easily of harvest. I peeled away the pulp to expose the hard endocarp, and discarded all seeds with insect holes or other damage, such as fungus infection. I tested for endocarp viability by placing them in water, and excluding the floating unsound ones, which were also likely to be parasitized or aborted. From the screened, pulp-free endocarps, I randomly selected 100 and measured (length and diameter), and weighed them to assess mean size and weight.

Analyzes. Due to the potential asynchronous fruiting pattern in S. loefgrenii, I compared, in the four periods of the year, the number of palms bearing fruits by Chi-square test, and fruit availability by ANOVA. I log transformed data on fruit number per infrutescence. Taking into account the potential intra-seasonal changes in general food resources availability and consequent chance of seed consumption, I tested $S$. loefgrenii endocarp removal in four periods of the year (see above). Then, as in principle predators should concentrate their activities in sites where foraging success is likely to be maximum (Schupp, 1988), foraging rodents, for example, might be differently attracted to depots conform endocarp number. In this respect, firstly I analyzed the relationship between initial number of endocarps, and the chance of removal (at least one of them) across seasons, through Chi-square contingency analysis. Following this premise, to evaluate the relationship between densities of $S$. loefgrenii stems (see above), and endocarp removal rate, Spearman rank correlation was used. The variables correlated were the number of stems within a $3 \mathrm{~m}$ ray of each depot and proportion of endocarps removed. Proportions of endocarp removal data were arc-sine transformed, and the number of stems was $\log$ transformed to reduce heteroscedasticity. Moreover, I 
assessed the relationship between endocarp removal rate and both initial number of endocarps and season at the end of each experiment (day 40) with a two-way analysis of variance (ANOVA). The first fixed factor had three levels: the number of endocarps per depot $(5,15$, and 40$)$, and the second fixed factor had four levels: the periods of the year (see above). The proportions of endocarps removed were arc-sine square-root transformed before analysis in order to approach normality and reduce heteroscedasticity. To improve the evaluation on the effect of the number of endocarps on removal rates, I also provided ANOVA values for each trial performed during the year.

To assess endocarp removal intensity caused by the initial number of endocarps per depot, I assessed the relationship $\left(\mathrm{I}=\mathrm{aR}^{\mathrm{b}}\right)$ between the initial number (I) and the number of removed endocarps (R). Then, I analyzed the initial-removed relationship by linear regression of $\log$ transformed values of $\mathrm{I}+1$ and $\mathrm{R}+1$ (power law equation), to normalize residuals. Indeed, with: $\log (\mathrm{y}+1)=\mathrm{a}+b \log (\mathrm{x}+1)$, I assessed distance-dependent effect, where $\mathrm{x}$ is the initial number of endocarps at a given depot and $y$ is the respective number of endocarps removed at the end of the experiment; $b$ is the slope representing the rate in which the number of endocarps removed increases in relation to the initial number of endocarps. The constant $b$ may be equal, minor or higher than 1 . Higher values imply in positive distance-dependence, while $b=1$, independence. Values of less than 1 imply in negative distance-dependence because per endocarp probability of removal is inversely related to endocarp density (Harms et al., 2000). To improve the evaluation on the occurrence of distance-dependence, the number of endocarps removed according to observed $b$ values were confronted (paired t-test) with the predicted number if $b=1$. Finally, due to the potential temporal variations in the intensity of endocarp removal, I compared the relationship between the initial and total number of endocarps removed ( $b$ values) during the four periods of the year by ANCOVA.

\section{Results}

Fruit availability and spatial distribution. Ripening fruits exhibited an ovoid shape including the endocarp with one seed. Endocarps had on average $( \pm \mathrm{sd}) 17.8 \pm 02.7 \mathrm{~mm}$ in length, $11.0 \pm 01.9$ in diameter, and $0.87 \pm 0.15 \mathrm{~g}$ in weight $(n=100)$. Palms bore fruits in the four periods of the year. In the first sampled period (Apr-Jun) 40 palms bore fruits, in the second 26, followed by 23, while in Jan-March 31 palms did the same (Chi-square: $\chi^{2}=5.50, \mathrm{p}=0.143, \mathrm{df}$ $=3$ ). In Apr-Jun, fruiting palms produced from 1 to 23 fruits $(7.46 \pm 5.23$ fruits, total $=306$ fruits $)$, in Jul-Sept they bore from 2 to 19 fruits $(9.96 \pm 4.58$, total $=259)$, in Oct-Dec from 1 to 29 fruits $(8.10 \pm 7.08$, total $=186)$, and in Jan-Mar from 2 to 30 fruits $(8.73 \pm 6.43$, total $=262)$. Despite of temporal variations in the average number of fruits produced, no significant difference emerged $(\mathrm{F}=2.09, \mathrm{p}=0.106$, Figure 1). I recorded a total of 438 stems present in the 45 plots. The number of stems per plot ranged from 0 to 33 (average [ $\pm \mathrm{se}$ ]: $0.34 \pm 0.04$ stems $/ \mathrm{m}^{2}$ ). This pronounced variation of the number of stems per plot conformed to a clumped distribution pattern in which $\mathrm{Ip}=0.53$. However, local S. loefgrenii density and the proportion of endocarps removed had no correlation across season (Spearman rank correlation, Apr-Jun: $r_{\mathrm{s}}=-0.02, \mathrm{p}=0.940$; Jul-Sept: $r_{s}=0.24, p=0.120$; Oct-Dec: $r_{s}=0.04, p=0.795$; Jan-March: $\left.\mathrm{r}_{\mathrm{s}}=-0.02, \mathrm{p}=0.882\right)$.

Negative distance-dependent removal of endocarps. In the four periods of the year no significant association emerged between initial number of endocarps and the chance of removal of at least one endocarp (Chi-square contingency analysis, $\chi^{2}=0.67$, df $\left.=6, p=0.994\right)$. Besides that, generally high proportions of endocarps were removed, namely $66.3 \%$ in Apr-Jun, 51.2\% (Jul-Sept), $61.2 \%$ (Oct-Dec), and 56.2\% (Jan-Mar; $\mathrm{n}=900$ in each period). Across the year most depots of 5 lost all endocarps. These depots suffered minor removal in Oct-Dec when $60 \%$ of them lost all endocarps, and $75 \%(n=75)$ of all endocarps were removed. On the other hand, in Jul-Sept, maximum removal occurred, so that $80 \%$ of depots lost all endocarps, while $92 \%$ of the total endocarps disappear. On average ( \pm se) from $3.73 \pm 0.47$ to $4.60 \pm 0.27$ endocarps were removed from these depots (Table 1). In Jul-Sept 46\% of depots of 15 lost all endocarps and $71 \%(n=225)$ of all endocarps were removed. In Oct-Dec, when highest removal occurred, $73 \%$ of depots lost all endocarps and $84 \%$ of the total was removed. On average from $10.60 \pm 1.37$ to $12.60 \pm 1.18$ endocarps were removed from these depots (Table 1). Finally, in Jul-Sept $13 \%$ of depots of 40 lost all endocarps and $39 \%$ of the total $(n=600)$ were removed. On the other hand, in Apr-Jun up to $27 \%$ of depots lost all endocarps and $59 \%$ of all endocarps disappear. On average from $15.53 \pm 3.77$ to $23.53 \pm 3.89$ endocarps were removed from these depots (Table 1). During the year, proportions (average \pm se) ranging from $0.73 \pm 0.01$ to $0.92 \pm 0.05$, were removed from depots of 5 . In the case of depots of 15 , proportions ranged from $0.71 \pm 0.09$ to $0.84 \pm 0.08$. However, in depots of 40, I often documented minor

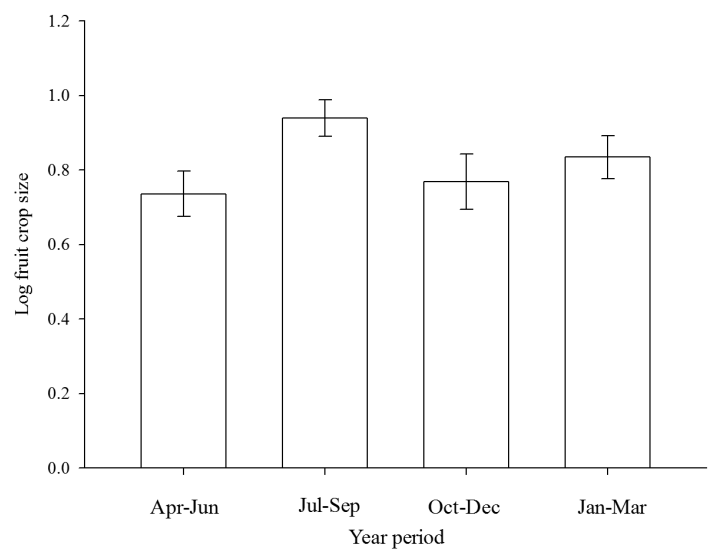

Figure 1. Syagrus loefgrenii mean fruit crop size produced across seasons in the Cerrado of Estação Ecológica de Itirapina (EEI, State of São Paulo Brazil, from April 2013 to March 2014). 
Table 1. Proportion of depots with complete endocarp removal, proportion of endocarps removed, as well as, average number $( \pm \mathrm{se})$ of endocarps removed from depots $(\mathrm{n}=15$ for each endocarp density). Also, analysis of variance (ANOVA) of the effect of number of endocarps per depot on the proportion of endocarps removed after 40 days. This experiment was performed in the Brazilian Cerrado (Brotas, State of São Paulo), during each of the four periods of the year. The proportions of endocarps removed were arc-sine square-root transformed before analysis.

\begin{tabular}{|c|c|c|c|c|}
\hline $\begin{array}{c}\mathbf{N}^{0} \text { endocarps/ } \\
\text { Depot }\end{array}$ & $\begin{array}{c}\text { Apr-Jun } \\
\text { (proportions: depots; } \\
\text { total of endocarps; } \\
\text { Mean } \pm \text { se) } \\
\end{array}$ & $\begin{array}{c}\text { Jul-Sep } \\
\text { (proportions: depots; } \\
\text { total of endocarps; } \\
\text { Mean } \pm \text { se) } \\
\end{array}$ & $\begin{array}{c}\text { Oct-Dec } \\
\text { (proportions: depots; } \\
\text { total of endocarps; } \\
\text { Mean } \pm \text { se) } \\
\end{array}$ & $\begin{array}{c}\text { Jan-Mar } \\
\text { (proportions: depots; } \\
\text { total of endocarps; } \\
\text { Mean } \pm \text { se) } \\
\end{array}$ \\
\hline \multirow[t]{2}{*}{5} & $0.8 ; 0.83$ & $0.8 ; 0.92$ & $0.6 ; 0.75$ & $0.4 ; 0.59$ \\
\hline & $4.13 \pm 0.48$ & $4.60 \pm 0.27$ & $3.73 \pm 0.47$ & $2.93 \pm 0.56$ \\
\hline \multirow[t]{2}{*}{15} & $0.73 ; 0.81$ & $0.47 ; 0.71$ & $0.73 ; 0.84$ & $0.47 ; 0.79$ \\
\hline & $12.14 \pm 1.49$ & $10.60 \pm 1.37$ & $12.60 \pm 1.18$ & $11.87 \pm 1.05$ \\
\hline \multirow[t]{3}{*}{40} & $0.27 ; 0.59$ & $0.13 ; 0.39$ & $0.20 ; 0.51$ & $0.33 ; 0.47$ \\
\hline & $23.53 \pm 3.89$ & $15.53 \pm 3.77$ & $20.40 \pm 4.09$ & $18.93 \pm 4.23$ \\
\hline & $($ Mean \pm se $)$ & $($ Mean \pm se $)$ & $($ Mean \pm se $)$ & $($ Mean \pm se $)$ \\
\hline 5 & $0.827 \pm 0.095^{*}$ & $0.920 \pm 0.054^{*}$ & $0.733 \pm 0.097$ & $0.590 \pm 0.113$ \\
\hline 15 & $0.809 \pm 0.099^{*}$ & $0.707 \pm 0.091^{*}$ & $0.840 \pm 0.078^{*}$ & $0.791 \pm 0.070^{*}$ \\
\hline 40 & $0.588 \pm 0.097$ & $0.388 \pm 0.094$ & $0.510 \pm 0.102$ & $0.473 \pm 0.106$ \\
\hline $\begin{array}{c}\text { ANOVA } \\
(\mathrm{df}=2,44)\end{array}$ & $\begin{array}{l}F=4.17 \\
p=0.026\end{array}$ & $\begin{array}{l}F=12.99 \\
p=0.0001\end{array}$ & $\begin{array}{l}F=4.51 \\
p=0.020\end{array}$ & $\begin{array}{l}F=3.18 \\
p=0.050\end{array}$ \\
\hline
\end{tabular}

* Indicate that mean proportion values of endocarp removal in these densities which were significantly higher than those present in depots of 40 .

proportions (from $0.39 \pm 0.09$ to $0.59 \pm 0.10$; Table 1 ). Indeed, removal rates were smaller in depots of 40 than in those ones of either 5 or 15 (Two-way ANOVA, F = 14.26, $\mathrm{p}=0.0001)$, and these differences were consistent across seasons $(F=0.56, p=0.644)$. Also, there was no significant interaction between the two main factors (initial number of endocarps and seasons), on mean proportion of endocarp removal $(\mathrm{F}=1.33, \mathrm{p}=0.247$, Figure 2, Table 1).

Endocarp removal conformed to negative distancedependence across seasons (Figure 3). Slopes for the initial-removed regressions were always less than 1 , so that the highest value was $b=0.74$ (Jan-Mar), while the lowest was $b=0.29$ (Jul-Sept; mean [ \pm se], $0.59 \pm 0.10$; Figure 2). Despite of variations these slope values had no significant difference (ANCOVA, $\mathrm{F}=1.74, \mathrm{p}=0.160$ ). The observed slopes of the log-log regression between the initial-removed number of endocarps were equal to, or significantly different from $b=0$ (Apr-Jun: $\mathrm{t}=4.74$, $\mathrm{r}^{2}=0.34, \mathrm{p}<0.0001$; Jul-Sept: $\mathrm{t}=1.79, \mathrm{r}^{2}=0.07$, $\mathrm{p}=0.084$; Oct-Dec: $\mathrm{t}=4.05, \mathrm{r}^{2}=0.28, \mathrm{p}<0.0001$; Jan-Mar: $\left.\mathrm{t}=4.654, \mathrm{r}^{2}=0.33, \mathrm{p}<0.0001\right)$. Also, observed endocarp removal was always significantly smaller than expect if $b=1$ (Apr-Jun: $\mathrm{t}=5.88, \mathrm{p}<0.0001$; Jul-Sept: $\mathrm{t}=12.70, \mathrm{P}<0.00001$; Oct-Dec: $\mathrm{t}=8.26, \mathrm{p}<0.00001$; Jan-Mar: $t=5.61, p<0.0001)$. Hence, the intensity of removal consistently decreases with the enhancement of endocarp number.

\section{Discussion}

Spatial distribution. In the Cerrado, palms tend to exhibit clumped distribution (Lima et al., 2003), which is the case of those ones dispersed by rodents (Almeida and Galetti, 2007). Such mammals often move seeds over short distances and may scatter-hoarding dispersed seeds generating clusters of buried seeds (Paschoal and Galetti, 1995; Peres and Baider, 1997). Small rodents, such as Clyomys bishop, are common in the study area (Vieira, 1997), and might be candidate to perform $S$. loefgrenii seed dispersal to favorable sites (Souza and Martins, 2002). Clyomys bishopi often move and cache seeds by less than $2 \mathrm{~m}$ from the parent plant; then these interactions might be, at least, the first step towards the pattern of distribution observed in S. loefgrenii (Almeida and Galetti, 2007).

Fruit production. Several studies have shown that palms, unlike other seasonal trees (e.g. Ragusa-Netto and Silva, 2007), exhibit reproductive phenological behavior extremely variable (Henderson, 2002). While, for example, flowering may be restricted to a particular season, fruiting is frequently non-seasonal (Peres, 1994, 2000). Then, palm nuts sustain a large proportion of the vertebrate community during annual seasons of food scarcity (Peres, 2000; Henderson, 2002). In the case of $S$. loefgrenii, the absence of major temporal variations in fruit production imply non-seasonal fruiting pattern, as in other palm species studied elsewhere (Henderson, 2002; Peres, 2000). Importantly, S. loefgrenii occurs in a seasonal area in which heavy rainfall is concentrated in few months. Then, in principle, each palm has its own particular fruiting interval, which is influenced by the level of accumulated resources required to initiate a fruit crop (Henderson, 2002). Consequently, fruiting in S. loefgrenii may figure as permanent source of food for frugivores in the Cerrado.

Distance dependence. Negative distance-dependence has been well documented in plant populations and communities (Harms et al., 2000; Comita and Hubbell, 


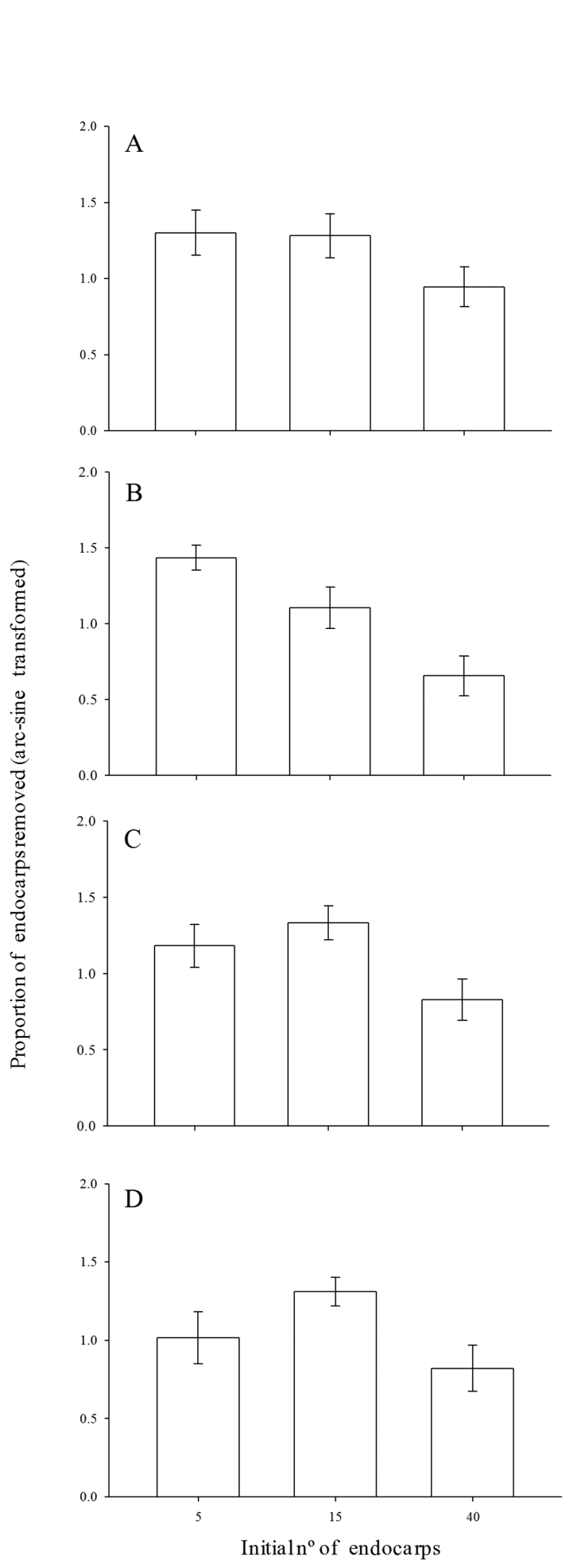

Figure 2. Mean removal rates of Syagrus loefgrenii endocarps in relation to the initial number, in the four periods of the year in the Cerrado of Estação Ecológica de Itirapina (EEI, State of São Paulo Brazil, from April 2013 to March 2014; A: April-June, B: July-September, C: October-December, D: January-March).

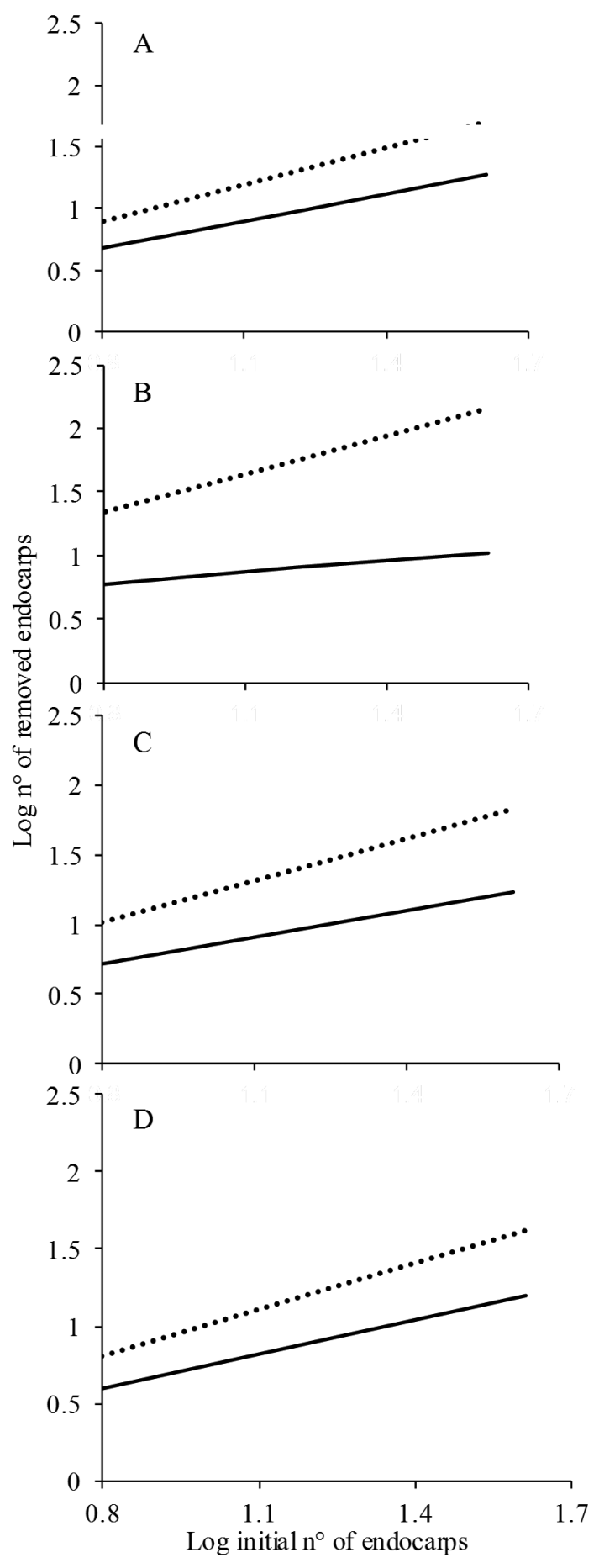

Figure 3. The relationship between initial number of endocarps and number of Syagrus loefgrenii endocarps removed across seasons in the Cerrado of Estação Ecológica de Itirapina (EEI, State of São Paulo Brazil, from April 2013 to March 2014; A: April-June, B: July-September, C: October-December, D: January-March). Continuous lines describe the log-log regressions indicating negative density-dependence (see text for further details). Dashed lines describe the expected relationship in the absence of density-dependence. 
2009; Jansen et al., 2014). In this study, endocarp removal rates were high ranging from 51 to $66 \%$. Rodents (putative removers) are mobile with high sensorial capabilities, and might easily detect piles of endocarps (Hulme, 1993). In fact, in the present study, they detected depots regardless of initial number of nuts, which is coherent with the year round abundance and activity patterns of these mammals (Vieira, 1997). Despite of that, they did not continue consuming palm seeds in dense nut patches (Schupp, 1988), as depots of 40 endocarps often experienced minor removal rates. Generalist rodents tend to concentrate their foraging activities at reduced distances from their holes (Howe, 1993). Presumably, when they detected S. loefgrenii nuts at a given place, only moderate amounts were consumed, as these mammals opportunistically eat a variety of seed species switching for different prey conform its abundance (Romo et al., 2004). In fact, specific seed predation by rodents is strongly influenced by the availability of alternative and more desirable food sources in the community (Forget, 1993; Forget et al., 1994). Besides that, rodents often cache seeds for periods of food scarcity, which may also influence their foraging efforts according to temporal and spatial patterns of food resources abundance (Howe, 1993; Vander Wall, 2010). Other possible cause for the reduced endocarp loss in those depots might be the low density or even absence of large rodents in the study site (Vieira, 1997). These mammals might consume or remove large number of diaspores at every foraging bout (Jansen et al., 2014).

The strong difference in removal rates caused by the initial number of endocarps emerged as functional response of rodents to prey availability (Hulme and Hunt, 1999). In the four periods of the year, neither the absolute number, nor the proportions of endocarps removed, a measure more directly related to the probability of endocarp survival, was, at least, proportional to the initial number of endocarps. Both measures pointed out negative distancedependent endocarp loss. The occurrence of similar removal rates across seasons, suggests the influence of permanent $S$. loefgrenii fruit production in providing food supply higher than the one required for sustaining rodents (Augspurger and Kitajima, 1992; Jansen et al., 2014). Indeed, I attempted to simulate the availability of fruit crop sizes often produced by $S$. loefgrenii (see above). Also, the evaluation was done at different periods of the year to assess endocarp removal patterns related to potential variations of $S$. loefgrenii fruit production and the activity of seed predators (Vieira, 1997). Compared to other large-sized Syagrus species, S. loefgrenii produces reduced number of fruits per infrutescence (Lorenzi et al., 2010). However, as this palm exhibit clumped distribution and fruiting is asynchronous, if at least, a group of neighboring stems fruit simultaneously 40 or more nuts might be available at a given site. Then, it is important to emphasize that when rodents are faced to abundant food supply they often scatter-hoarding seeds for further consumption (Vander Wall, 2010). As result, these mammals perform seed dispersal away from seed source reducing post-dispersal infestation by parent-associated predators and pathogens, besides the fact that the burial of seeds enhances seed survival and seedling establishment (Jansen et al., 2008; Vander Wall, 2010). Taking into account those potential seed fate, if seed predation may limits recruitment in $S$. loefgrenii, the erratic production of dense fruit patches, within a population fruiting asynchronously, may be advantageous for seed survival as post dispersal seed predators may be swamped (Jansen et al., 2014).

\section{Acknowledgements}

The author is grateful to an anonymous reviewer for the constructive comments on an earlier version of this study. Márcia Grando Ragusa kindly provided field assistance. Financial support was provided by $\mathrm{CNPq}$.

\section{References}

ALMEIDA, B. and GALETTI, M., 2007. Seed dispersal and spatial distribution of Attalea geraensis (Arecaceae) in two remnants of Cerrado in Southeastern Brazil. Acta Oecologica, vol. 32, no. 2, pp. 180-187. http://dx.doi.org/10.1016/j.actao.2007.04.001.

AUGSPURGER, C.K. and KITAJIMA, K., 1992. Experimental studies of seedling recruitment from contrasting seed distributions. Ecology, vol. 73, no. 4, pp. 1270-1284. http://dx.doi.org/10.2307/1940675.

BAGCHI, R., SWINFIELD, T., GALLERY, R.E., LEWIS, O.T., GRIPENBERG, S., NARAYAN, L. and FRECKLETON, R.P., 2010. Testing the Janzen-Connell mechanism: pathogens cause overcompensating density dependence in a tropical tree. Ecology Letters, vol. 13, no. 10, pp. 1262-1269. http://dx.doi. org/10.1111/j.1461-0248.2010.01520.x. PMid:20718845.

BECK, H. and TERBORGH, J., 2002. Groves versus isolates: how spatial aggregation of Astrocaryum murumuru palms affects seed removal. Journal of Tropical Ecology, vol. 18, no. 02, pp. 275-288. http://dx.doi.org/10.1017/S0266467402002183.

BUENO, A.A., LAPENTA, M.J., OLIVEIRA, F. and MOTTAJUNIOR, J.C., 2004. Association of the "IUCN vulnerable" spiny rat Clyomys bishopi (Rodentia: Echimyidae) with palm trees and armadillo burrows in southeastern Brazil. Revista de Biologia Tropical, vol. 52, no. 4, pp. 1009-1011. PMid:17354413.

CHAUVET, S. and FORGET, P.M., 2005. Edge effects on postdispersal seed removal in a fragmented rain forest in French Guiana. Journal of Tropical Ecology, vol. 21, no. 1, pp. 113-116. http://dx.doi.org/10.1017/S0266467404001944.

CHAUVET, S., FEER, F. and FORGET, P.M., 2004. Seed fate of two Sapotaceae species in a Guianan rain forest in the context of escape and satiation hypotheses. Journal of Tropical Ecology, vol. 20, no. 1, pp. 1-9. http://dx.doi.org/10.1017/S0266467404006121.

COMITA, L.S. and HUBBELL, S.P., 2009. Local neighborhood and species' shade tolerance influence survival in a diverse seedling bank. Ecology, vol. 90, no. 2, pp. 328-334. http://dx.doi. org/10.1890/08-0451.1. PMid:19323215.

EISERHARDT, W.L., SVENNING, J.C., KISSLING, W.D. and BALSLEV, H., 2011. Geographical ecology of the palms (Arecaceae): determinants of diversity and distributions across spatial scales. Annals of Botany, vol. 108, no. 8, pp. 1391-1416. http://dx.doi.org/10.1093/aob/mcr146. PMid:21712297. 
FORGET, P.M., 1993. Post-dispersal predation and scatterhoarding of Dipteryx panamensis (Papilionaceae) seeds by rodents in Panama. Oecologia, vol. 94, no. 2, pp. 255-261. http://dx.doi. org/10.1007/BF00341325.

FORGET, P.M., MUNOZ, E. and LEIGH, J.R.E.G., 1994. Predation by rodents and bruchid beetles on seeds of Scheelea palms on Barro Colorado Island, Panama. Biotropica, vol. 26, no. 4, pp. 420-426. http://dx.doi.org/10.2307/2389236.

HARMS, K.E., WRIGHT, S.J., CALDERON, O., HERNANDEZ, A. and HERRE, E.A., 2000. Pervasive density-dependent recruitment enhances seedling diversity in a tropical forest. Nature, vol. 404, no. 6777, pp. 493-495. http://dx.doi.org/10.1038/35006630. PMid:10761916.

HENDERSON, A., 2002. Evolution and ecology of palms. New York: The New York Botanical Garden Press. 198 p.

HOWE, H.F., 1993. Aspects of variation in a neotropical seed dispersal system. Vegetatio, vol. 107, pp. 149-162.

HULME, P. and HUNT, M., 1999. Rodent post-dispersal seed predation in deciduous woodland: predator response to absolute and relative abundance of prey. Journal of Animal Ecology, vol. 68, no. 2, pp. 417-428. http://dx.doi.org/10.1046/j.13652656.1999.00294.x.

HULME, P.E., 1993. Post-dispersal seed predation by small mammals. Symposia of the Zoological Society of London, vol. 65 , pp. 269-287.

HULME, P.E., 1998. Post-dispersal seed predation: consequences for plant demography and evolution. Perspectives in Plant Ecology, Evolution and Systematics, vol. 1, no. 1, pp. 32-46. http://dx.doi. org/10.1078/1433-8319-00050.

JANSEN, P.A., BOHLMAN, A., GARZON-LOPEZ, C.X., OLFF, H., MULLER-LANDAU, H.C. and WRIGHT, S.J., 2008. Large-scale spatial variation in palm fruit abundance across a tropical moist forest estimated from high-resolution aerial photographs. Ecography, vol. 31, pp. 33-42. http://dx.doi. org/10.1111/j.2007.0906-7590.05151.x.

JANSEN, P.A., VISSER, M.D., WRIGHT, J.S., RUTTEN, G. and MULLER-LANDAU, H.C., 2014. Negative density dependence of seed dispersal and seedling recruitment in a Neotropical palm. Ecology Letters, vol. 17, no. 9, pp. 1111-1120. http://dx.doi. org/10.1111/ele.12317. PMid:25039608.

JANZEN, D.H., 1970. Herbivores and the number of tree species in tropical forests. American Naturalist, vol. 104, no. 940, pp. 501-528. http://dx.doi.org/10.1086/282687.

KAHN, F. and MEJIA, K., 1991. The palm communities of two "terra firme" forests in Peruvian Amazonia. Principes, vol. 35, pp. 22-26.

KILTIE, R.A., 1981. Distribution of palm fruits on a rain forest floor: why white-lipped peccaries forage near objects. Biotropica, vol. 13, no. 2, pp. 141-145. http://dx.doi.org/10.2307/2387716.

KREBS, C.J., 1989. Ecological methodology. New York: Harper \& Row. 654 p.

LIMA, E.S., FELFILI, J.M., MARIMON, B.S. and SCARIOT, A., 2003. Diversidade, estrutura e distribuição espacial de palmeiras em um cerrado sensu stricto no Brasil Central-DF. Revista Brasileira de Botanica. Brazilian Journal of Botany, vol. 26, no. 3, pp. 361-370. http://dx.doi.org/10.1590/S0100-84042003000300009.
LORENZI, H., NOBLICK, L., KAHA, F. and FERREIRA, E., 2010. Flora Brasileira: Arecaceae (Palms). Nova Odessa: Instituto Plantarium. 384 p.

MARES, M.A., ERNEST, K.A. and GETTINGER, D.D., 1986. Small mammal community structure and composition in the Cerrado Province of central Brazil. Journal of Tropical Ecology, vol. 2, no. 04, pp. 289-300. http://dx.doi.org/10.1017/S0266467400000948.

MORISITA, M., 1962. I $\sigma$-Index, a measure of dispersion of individuals. Researches on Population Ecology, vol. 4, no. 1, pp. 1-7. http://dx.doi.org/10.1007/BF02533903.

MOTTA-JUNIOR, J.C., DEVELEY, P.F. and GRANZINOLLI, M.A.M., 2008. Aves da Estação Ecológica de Itirapina, estado de São Paulo, Brasil. Biota Neotropica, vol. 8, no. 3, pp. 207-227.

MYSTER, R.W. and PICKETT, S.T.A., 1993. Effects of litter, distance, density and vegetation patch type on postdispersal tree seed predation in old fields. Oikos, vol. 66, no. 3, pp. 381-388. http://dx.doi.org/10.2307/3544932.

NATHAN, R. and CASAGRANDI, R., 2004. A simple mechanistic model of seed dispersal, predation and plant establishment: Janzen-Connell and beyond. Journal of Ecology, vol. 92, no. 5, pp. 733-746. http://dx.doi.org/10.1111/j.0022-0477.2004.00914.x.

PACKER, A. and CLAY, K., 2003. Soil pathogens and Prunus serotina seedling and sapling growth near conspecific trees. Ecology, vol. 84, no. 1, pp. 108-119. http://dx.doi.org/10.1890/00129658(2003)084[0108:SPAPSS]2.0.CO;2.

PASCHOAL, M. and GALETTI, M., 1995. Seasonal food use by the Neotropical squirrel Sciurus ingrami in the southeastern. Biotropica, vol. 27, no. 2, pp. 268-273. http://dx.doi.org/10.2307/2389006.

PERES, C.A. and BAIDER, C., 1997. Seed dispersal, spatial distribution and population structure of Brazilnut trees (Bertholletia excelsa) in southeastern Amazonia. Journal of Tropical Ecology, vol. 13, no. 04, pp. 595-616. http://dx.doi.org/10.1017/ S0266467400010749.

PERES, C.A., 1994. Composition, density, and fruiting phenology of arborescent palms in an Amazonian terra firme forest. Biotropica, vol. 26, no. 3, pp. 285-294. http://dx.doi.org/10.2307/2388849.

PERES, C.A., 2000. Identifying keystone plant resources in tropical forests: the case of gums from Parkia pods. Journal of Tropical Ecology, vol. 16, no. 2, pp. 287-317. http://dx.doi.org/10.1017/ S0266467400001413.

RAGUSA-NETTO, J. and SILVA, R.R., 2007. Canopy phenology of a dry forest in western Brazil. Brazilian Journal of Biology = Revista Brasileira de Biologia, vol. 67, no. 3, pp. 569-575. http:// dx.doi.org/10.1590/S1519-69842007000300024. PMid:18094842.

ROMO, M., TUOMISTO, H. and LOISELLE, B.A., 2004. On the density-dependence of seed predation in Dipteryx micrantha, a bat-dispersed rain forest tree. Oecologia, vol. 140, no. 1, pp. 76-85. http://dx.doi.org/10.1007/s00442-004-1502-x. PMid:15148597.

SCHUPP, E.W., 1988. Seed and early seedling predation in the forest understory and in tree fall gaps. Oikos, vol. 51, no. 1, pp. 71-78. http://dx.doi.org/10.2307/3565808.

SMYTHE, N., 1989. Seed survival in the palm Astrocaryum standleyanum: evidence for dependence upon its seed dispersers. Biotropica, vol. 21, no. 1, pp. 50-56. http://dx.doi.org/10.2307/2388441.

SORK, V.L., 1993. Evolutionary ecology of mast-seeding in temperate and tropical oaks (Quercus spp.). Vegetatio, vol. 107, pp. 133-147. 
SOUZA, A.F. and MARTINS, F.R., 2002. Spatial distribution of an undergrowth palm in fragments of the Brazilian Atlantic Forest. Plant Ecology, vol. 164, no. 2, pp. 141-155. http://dx.doi. org/10.1023/A:1021229832634.

STEVEN, D., 1991. Experiments on mechanisms of tree establishment in old-field succession: seedling survival and growth. Ecology, vol. 72, no. 3, pp. 1076-1088. http://dx.doi.org/10.2307/1940607.

SWAMY, V. and TERBORGH, J., 2010. Distance responsive natural enemies strongly influence seedling establishment patterns of multiple species in an Amazonian rain forest. Journal of Ecology, vol. 98, no. 5, pp. 1096-1107. http://dx.doi.org/10.1111/j.13652745.2010.01686.x

TANNUS, J.L. and ASSIS, M.A., 2004. Composição de espécies vasculares de campo sujo e campo úmido em área de cerrado, Itirapina-SP, Brasil. Revista Brasileira de Botanica. Brazilian Journal of Botany, vol. 27, no. 3, pp. 489-506. http://dx.doi. org/10.1590/S0100-84042004000300009.

TERBORGH, J., 2012. Enemies maintain hyperdiverse tropical forests. American Naturalist, vol. 179, no. 3, pp. 303-314. http:// dx.doi.org/10.1086/664183. PMid:22322219.
VANDER WALL, S.B., 2010. How plants manipulate the scatterhoarding behaviour of seed-dispersing animals. Philosophical Transactions of the Royal Society of London. Series B, Biological Sciences, vol. 365, no. 1542, pp.989-997. http://dx.doi.org/10.1098/ rstb.2009.0205. PMid:20156821.

VIEIRA, E.M., 1999. Small mammal communities and fire in the Brazilian Cerrado. Journal of Zoology, vol. 249, no. 1, pp. 75-81. http://dx.doi.org/10.1111/j.1469-7998.1999.tb01061.x.

VIEIRA, M.V., 1997. Dynamics of a rodent assemblage in a cerrado of southeast Brazil. Revista Brasileira de Biologia . Brazilian Journal of Biology $=$ Revista Brasileira de Biologia, vol. 57, pp. 99-107.

WRIGHT, J.S., 2002. Plant diversity in tropical forests, p. a review of mechanisms of species coexistence. Oecologia, vol. 130, no. 1, pp. 1-14. http://dx.doi.org/10.1007/s004420100809.

WRIGHT, S.J., 1990. Cumulative satiation of a seed predator over the fruiting season of its host. Oikos, vol. 58, no. 3, pp. 272-276. http://dx.doi.org/10.2307/3545217.

ZONA, S. and HENDERSON, A., 1989. A review of animalmediated seed dispersal of palms. Selbyana, vol. 11, pp. 6-21. 